\title{
A Comprehensive Review of Possible Immune Responses against Novel SARS-CoV-2 Coronavirus: Vaccines Strategies and Challenges
}

\author{
Shahriar A ${ }^{1 *}$, Mahmud $\mathrm{AR}^{2}$, Ahmed $\mathrm{H}^{3}$, Rahman \\ $\mathrm{N}^{4}$ and Khatun $\mathrm{MC}^{4}$ \\ ${ }^{1}$ Department of Microbiology, Stamford University \\ Bangladesh, 51 Siddeswari Road, Dhaka, Bangladesh \\ ${ }^{2}$ Department of Biochemistry and Molecular Biology, \\ Mawlana Bhashani Science and Technology University, \\ Santosh, Tangail, Bangladesh \\ ${ }^{3}$ Department of Biotechnology and Genetic Engineering, \\ University of Development Alternative (UODA), \\ Dhanmondi R/A, Dhaka, Bangladesh \\ ${ }^{4}$ Department of Biochemistry and Molecular Biology, \\ J ahangirnagar University, Savar, Dhaka, Bangladesh \\ *Corresponding author: Asif Shahriar, Research \\ Assistant, Department of Microbiology, Stamford \\ University Bangladesh, 51 Siddeswari Road, Dhaka 1217, \\ Bangladesh
}

Received: February 19, 2021; Accepted: March 13, 2021; Published: March 20, 2021

\begin{abstract}
The current deadly COVID-19 pandemic caused by the SARS-CoV-2 virus appeared in late December 2019 in Wuhan, China, and spread globally. The epidemic is still spreading, and there are no effective strategies to prevent the infection. Many companies and institutes are trying to figure out the solution by developing vaccines and antiviral drugs, but still, it requires advanced research and long times. However, scientists were able to decide that Immunological response induction is the ultimate target for any vaccine candidate. The immune response to SARS-CoV-2 involves all the immune system components that together appear responsible for viral elimination and recovery from the infection. Many immunological studies have been conducted based on T cell immunity because dependence on the antibody is not the only solution whether some studies showed that antibody wiped out very early. Some studies suggest that cytotoxic $T$ cells and memory $T$ cells give long term immunity. Nonetheless, the vaccines racing from the front provide promising results in various phases (preliminary to phase 2) to induce enough potent neutralizing antibodies. Besides, some vaccines showed $\mathrm{T}$ cell-based immune response, which may induce long-term immunity memory $\mathrm{T}$ cells. This review mainly illustrated potential vaccine development strategies and challenges by focusing on T-cellbased immune response against SARS-CoV-2 Coronavirus.
\end{abstract}

Keywords: SARS-CoV-2; T-cell based immunity; Cytotoxic $\mathrm{T}$ cells; Vaccines; Immunological paradox

\section{Introduction}

Severe Acute Respiratory Syndrome Coronavirus 2 (SARS$\mathrm{CoV}-2$ ) is one of the deadliest viruses among the other viruses. The virus has significantly impacted the world and has brought serious concern. The adaptive immune system is the vital player to fight against this pandemic. The adaptive immune system's central players are mainly two types of $\mathrm{T}$ cells and plasma B cells. However, the mechanism of human $\mathrm{T}$ cells functions in opposition to the SARS$\mathrm{CoV}-2$ virus is still opaque. It is crucial to perceive how the $\mathrm{T}$ cells respond to this novel virus.

Understanding the response of our immune system against COVID-19 may play a pivotal role. This knowledge is also essential to develop a well-performed vaccine. Cytotoxic T cells attack viruscontaminated cells directly, and helper T cells vivify B cells to produce antibodies against that virus's particular protein. It is unclear whether adaptive immune responses against SARS-CoV-2 are preventive or harmful [1]. As we know very little about SARS-CoV-2. There are many inquiries than answers for the recently recognized infection, including the etiology, the study of disease transmission, the basic premise, a system of pathogenesis, neurotic invulnerable reaction, and so on. Particularly, the host's cellular and humoral immune response in response to the virus infection crucial for vaccine design remains unclear. All these important aspects need to be addressed by basic research shortly for successful vaccine development [2].
Recently, a team lead by Scripps Research has discovered antibodies from the convalescent person that yield robust protection against the virus SARS-CoV-2.

The team quickly screened over 1800 antibodies and analyzed animal models to experiment with shielding [3]. They separated strong Neutralizing Antibody (nAbs) against two epitopes of receptor-binding domains, which can distinguish non-RBD epitopes on the spike protein [3]. They used Syrian hamsters to show the protection of a $\mathrm{nAb}$ against SARS-CoV-2. This evaluation proposes nAbs in preventive treatment and the possible remedy of COVID-19 [3]. Neutralizing antibodies, CD4+, and CD8+ T cells are affiliated with the ferocity of COVID-19 [4]. We have to focus on B-cell and T-cell responses to help flourish a potent contemporary vaccine [4]. A recent study in the U.K. showed that persons recovered from severe conditions showed strong and varied $\mathrm{T}$ cells response than those recovering from mild conditions [5]. However, their $\mathrm{T}$ cells react to spike proteins and the virus's internal components [5].

Humoral immunity and memory B cell response are not longlasting in SARS-CoV patients through robust neutralizing specific antibody induced against SARS-CoV spike glycoprotein [4]. In SARS-CoV, affected severe patients manifested an extreme reduction in $\mathrm{T}$ cell quantity in the blood $[6,37,38,88]$. Previous studies have demonstrated that full-length $S$ protein can cause severe liver damage and may result in enhanced infection, defined as Antibody-
Austin J Microbiol - Volume 6 Issue 1 - 2021

ISSN: 2471-0296 | www.austinpublishinggroup.com

Shahriar et al. @ All rights are reserved
Citation: Shahriar A, Mahmud AR, Ahmed H, Rahman N and Khatun MC. A Comprehensive Review of Possible Immune Responses against Novel SARS-CoV-2 Coronavirus: Vaccines Strategies and Challenges. Austin J Microbiol. 2021; 6(1): 1028. 


\section{Vaccine Development for Covid-19 : Types \& Challenge}
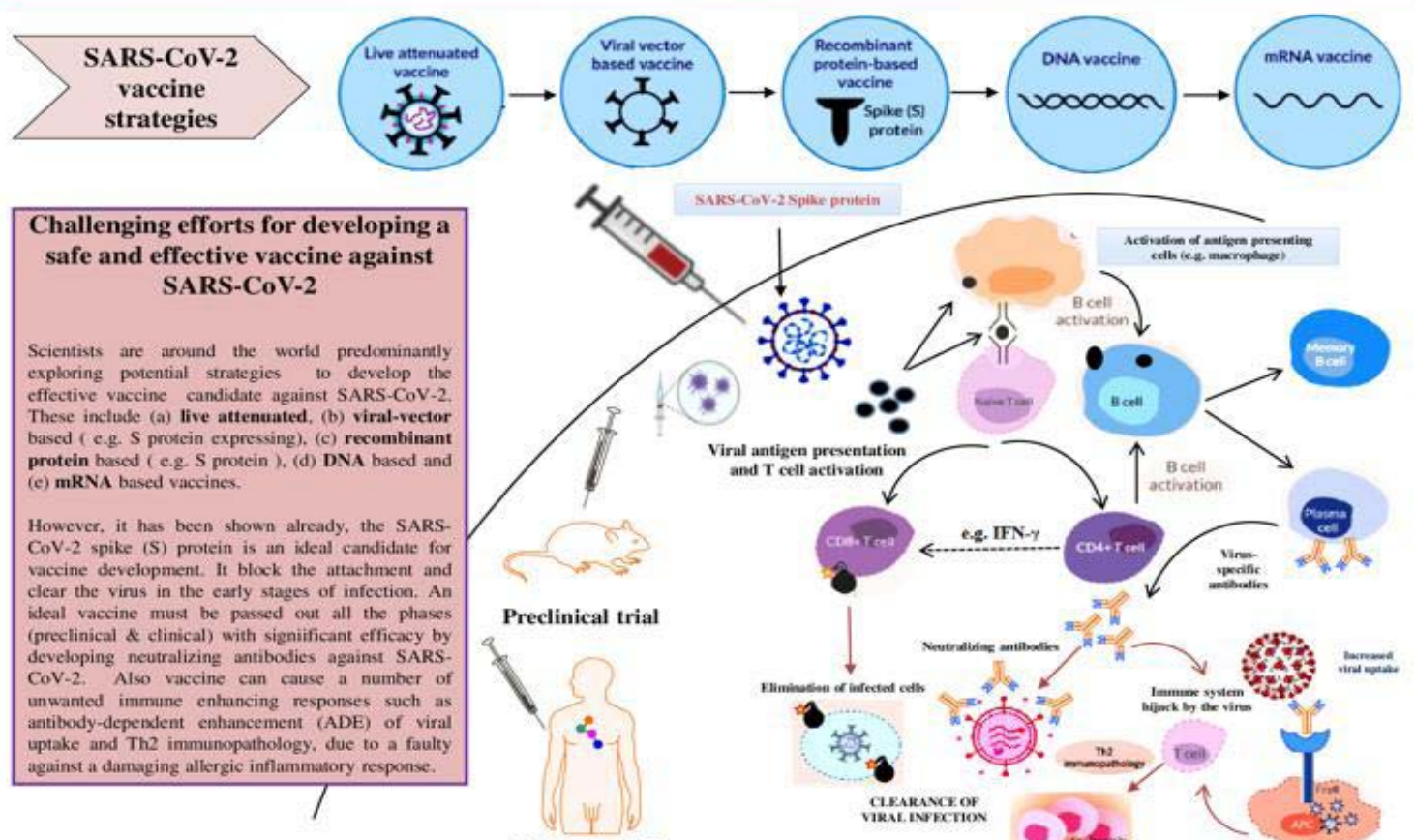

Clinical trial

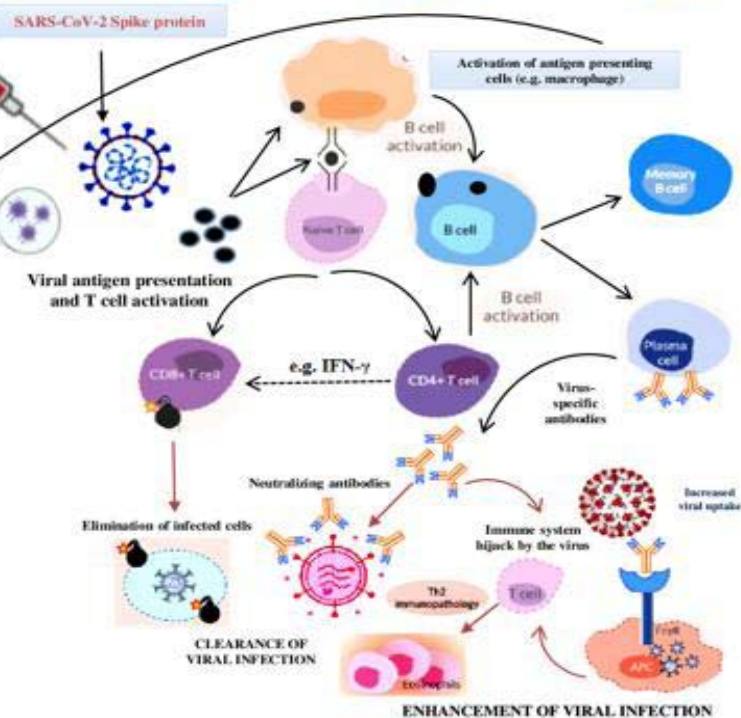

Figure 1: Strategies of vaccine development. There are several types of strategies have been followed to develop a potent vaccine against SARS-CoV-2. For instance, Live attenuated vaccine, mRNA vaccine, D.N.A vaccine, viral vector-based vaccine, Recombinant protein-based vaccine etc. Most of the vaccines quarry spike protein of SARS-CoV-2. Every ideal and effective vaccine should complete their preclinical and clinical phases to prove their effectiveness and potency. After the entry of viral antigens via vaccination, A.P.C.S are activated, and they present antigen to B cells to activate humoral immunity. Then B cells differentiate into memory B cells, preventing further infection and plasma cells that produce virus-specific neutralizing antibodies. Viral antigens activate naive T cells that further differentiate into cytotoxic T cells (CD8+ T cells) and helper T cells (CD4+ T cells). Helper T cells secrete I.F.N. - Y and mediate CD8+ T-cell immune response to destroy pathogens. Sometimes, the immune system is seized by the virus, which may promote A.D.E Furthermore, Th2 related interleukins stimulate the pulmonary eosinophil responsible for Th2 immunopathology.

Dependent Enhancement (ADE). S protein-specific antibodies may probably cause this effect. Further, there is a report that the enhanced virulence mediated by the murine coronavirus, mouse hepatitis virus strain J.H.M, is associated with glycine at residue 310 of the spike glycoprotein, and this mutation may contribute to the spreading within the Central Nervous System (CNS) [2].

Although the rapid development of the SARS-CoV-2 vaccine, it still faces many challenges with unknown knowledge, including the antigenic characteristics of the SARS-CoV-2, the influence of antigenic variation, the protective immune response of the host, the protection of the elderly population, and the downstream manufacturing process of the new vaccine [7]. Nonetheless, to accelerate the production of emerging technology-based vaccines against SARS-CoV-2, it has to face challenges to implement, including revealing the relationship between virology and immunology, followed by production capability. A long-term study on several types of viruses like- Dengue virus, influenza virus, etc., helps accelerate vaccine discovery because we know in detail the antigenicity of viral structural proteins and protective immunity characteristics [8]. However, many vaccines with different approaches entered into human trials, though safety and efficacy data in details are not known yet. Researchers are taking advantage to make most of the vaccines against SARS-CoV-2 from either previous study on SARS-CoV, MERS-CoV, and other types of coronavirus or developmental strategies of other vaccines helping [9]. In this review, we discussed about a variety of immune responses, COVID-19 vaccine development strategies, the prospectus of COVID-19 vaccines, and upcoming challenges.

\section{Strategies for Covid-19 Vaccine Development}

Scientists worldwide are implementing various technologies; some of that vaccine's strategy never implemented or licensed before [10]. The adaptive immune system is the key player in developing immunity against SARS-CoV-2. All vaccines target to induce the immune response against an antigen, whatever the strategies are targeted spike protein or not [10]. Various vaccination strategies for SARS-CoV-2 are implemented, such as D.N.A vaccines, R.N.A vaccines, killed or inactivated vaccines, live attenuated vaccines, and viral vector-based vaccines [11] (Figure 1).

Among all of these vaccines, killed/inactivated vaccines and the live attenuated vaccines are induced immunity against the whole virion. In contrast, other vaccines target $S$ protein [11]. A vaccine's finalization may take several months to years, even after being tested on the animal model [11]. S protein target may be the best strategy for developing a potent vaccine against SARS-CoV, MERS-CoV, SARS- 
Table 1: Possible strengths and weaknesses of different types of the vaccine against SARS-CoV-2.

\begin{tabular}{|c|c|c|c|}
\hline Types of Vaccines & Strengths & Weaknesses & Reference \\
\hline D.N.A & $\begin{array}{l}\text { - } \quad \text { No need to touch infectious agents. } \\
\text { - Can be implemented in immunocompromised } \\
\text { induvial. } \\
\text { - } \quad \text { Induce both humoral and cell-mediated immunity. } \\
\text { - Scaling up manufacturing is possible. } \\
\text { Provide long term stability. }\end{array}$ & $\begin{array}{l}\text { - } \quad \text { No licensed D.N.A vaccines in the market } \\
\text { yet. } \\
\text { - } \quad \text { Other immune responses may occur. } \\
\text { Host cell genomic incorporation may occur. }\end{array}$ & [11] \\
\hline R.N.A & $\begin{array}{l}\text { - } \quad \text { Fast design and scaling up production possible. } \\
\text { - } \quad \text { So need to touch infectious agents. } \\
\text { - } \quad \text { Induce both humoral and cell-mediated immunity. }\end{array}$ & $\begin{array}{l}\text { - } \quad \text { No licensed R.N.A vaccines in the market } \\
\text { yet. } \\
\text { May induce inflammatory reactions. } \\
\text { Booster dose likely necessary to earn long } \\
\text { lasting immunity. }\end{array}$ & [11] \\
\hline Protein & $\begin{array}{l}\text { - } \quad \text { No need to touch infectious agents. } \\
\text { - } \quad \text { Robust responses of antibody. } \\
\text { - } \quad \text { Viral protein simulate like real virus. }\end{array}$ & $\begin{array}{l}\text { - } \quad \text { Adjuvants are needed. } \\
\text { Rapid production and manufacturing may } \\
\text { face challenge. }\end{array}$ & [11] \\
\hline $\begin{array}{l}\text { Viral Vector (replicating } \\
\text { or non-replicating) }\end{array}$ & $\begin{array}{l}\text { The safety and immune responses capability are } \\
\text { known for many years in the field of gene therapy. } \\
\text { Provide robust humoral and cell-mediated immune } \\
\text { responses. }\end{array}$ & $\begin{array}{l}\text { - } \quad \text { Show adverse effects on oncogenesis. } \\
\text { Pre-existing immunity against the Vector } \\
\text { may decrease the potentiality of a vaccine. } \\
\text { - } \quad \text { Many types of immunogenicity may occur. } \\
\text { Tough to scale up manufacturing. }\end{array}$ & [11] \\
\hline Live attenuated virus & $\begin{array}{ll}- & \text { Verified technology. } \\
\text { - } & \text { Induce robust immune response. } \\
\text { - } & \text { Multivalent. } \\
\text { - } & \text { No need adjuvants. } \\
\end{array}$ & $\begin{array}{l}\text { - } \quad \text { Biosafety level maintenance must need. } \\
\text { May recover virulence. }\end{array}$ & [11] \\
\hline Inactivated virus & $\begin{array}{l}-\quad \text { Verified technology. } \\
\text { - } \quad \text { Induce robust immune response. } \\
\text { - } \quad \text { Multivalent. } \\
\text { No need adjuvants. }\end{array}$ & $\begin{array}{l}\text { - } \quad \text { Biosafety level maintenance must need. } \\
\text { Rapid production may be tough. }\end{array}$ & [11] \\
\hline
\end{tabular}

$\mathrm{CoV}-2$ due to its significant role in the interaction between viruses and cells $[12,13]$. A sequencing study showed that $80 \%$ of constructional closeness shared between SARS-CoV and SARS-CoV-2 [11].

In previous studies on the SARS-CoV vaccine, it was noticed that lung damage occurred by a live virus. Brought immunopathological complications like inflammation and penetration of eosinophils made worsen the disease's state [14]. The possible strengths and weaknesses of different vaccination strategies against SARS-CoV-2 are considered in (Table 1).

\section{Immunological Responses of Asymptomatic Sars-Cov-2 Infections}

A study conducted in a district of China named Wanzhou included over 37 asymptomatic individuals. They showed no clinical manifestations in the early 14 days and at the time of hospitalization but were diagnosed positive with RT-PCR test [15]. The IQR (Interquartile range) of the asymptomatic group was 15-26 days [15]. Viral shedding means a virus can be replicated inside the body and released into the environment; the asymptomatic group showed a remarkably stable viral shedding condition [15]. In acute conditions, the IgG levels were lower in asymptomatic than those who showed symptoms. Because of the weaker immune response of asymptomatic individuals, they showed lower levels of 18 pro-inflammatory, and anti-inflammatory cytokines than symptomatic one and also $40 \%$ of persons who do not show any symptoms became seronegative were $12.9 \%$ of the group of people who exhibited symptoms showed negative for IgG [15]. Another study conducted on 303 patients in a community treatment center in Cheonan, Republic of Korea, among them, 110 individuals are asymptomatic (36.3\%) [16]. Among those asymptomatic individuals, the median time was 17 from the period of diagnosis to the first counterbalance transformation [16]. Further, a cohort study in South Korea showed that among 10,273 individuals, more than $60 \%$ of patients (6350) were asymptomatic [17]. "Shield immunity" is dependent on the strength and duration of immunity [18]. Antibodies against SARS-CoV or MERS-CoV were found even after 1-year previous study suggests [19]. However, some viewpoints are also constitutional. Some available data showed that the significant adaptive immune responses might not occur, [20] and also, strong protective immunity may not develop. T-cell responses against the SARS-CoV-2 spike protein have been characterized and correlate well with IgG and IgA antibody titers in COVID-19 patients, which has important implications for vaccine design long-term immune response $[1,21]$. It is currently unknown whether antibody responses or T-cell responses in infected people confer protective immunity, and if so, how strong response is needed for this to occur. Lymphocytes include- T cells (CD4+ T cells \& CD8+ T cells) and B cells, NK. cells play orchestrally to induce inflammation in COVID-19 patients; among them, CD8+ T cells act as major inflammatory cells and are associated with viral clearance $[1,21-23]$. It is observed that CD4+ T cells and CD8+ T cells, both T lymphocytes quantity declined in mild and moderately ill patients. However, in severe cases, the quantity of $\mathrm{T}$ lymphocytes declined alarmingly. Several investigations showed that poor treatment outcome is related to the low quantity of CD8+ $\mathrm{T}$ cells and B lymphocytes with an elevated ratio of CD4+/CD8+. Moreover, CD4+ T cells induced IFN- $\gamma$ level to lower in severely ill patients than moderate individuals [22].

\section{Humoral Immume Response to Sars-Cov-2 Virus}

The antibody-mediated immune response against the SARS$\mathrm{CoV}-2$ virus is aimed to the spike glycoprotein and $\mathrm{N}$ (nucleocapsid) protein [4]. The spike glycoprotein (M.W: $180 \mathrm{kD}$ ) carries two domains- the N-terminal domain is known as S1 and C-terminal 


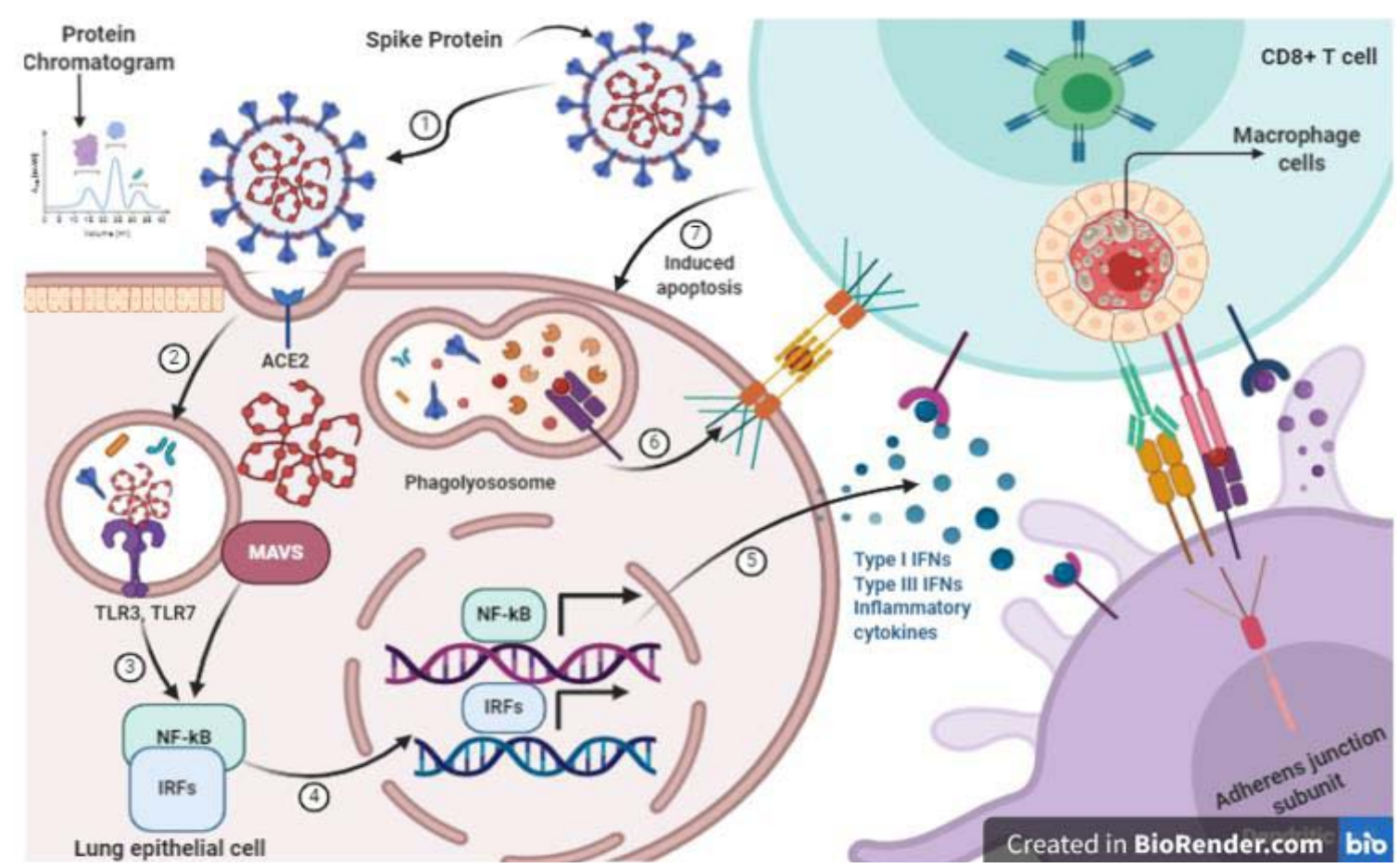

Figure 2: Immune Responses to SARS-CoV-2 (Created with BioRender.com). SARS-CoV-2 are RNA viruses, some of which; 1) can infect human lung epithelium via the receptor ACE2; 2) Endosomal and cytoplasmic sensors, TLR3/7 and MAVS, are activated by viral R.N.A; 3) TLR3/7, and MAVS receptors trigger Interferon Regulatory Factors (IRFs) and NFkB; 4) NFkB and I.R.F.S are transcription factors that bind with the region of D.N.A that regulate the transcription of inflammatory cytokines and interferons; 5) NFkB contentiously induces inflammatory cytokines and Interferons (IFN) and Interferon Regulatory Factors (IRFs), respectively, and these aforementioned receptors activate these Interferon Regulatory Factors; 6) Dendritic Cells (DCs) sample antigen and migrate to lymphoid organs to prime adaptive immunity, whereas; 7) apoptosis induced by CD8 T cells when antigen recognition on DCs or infected cells that inhibit the viral replication and induced the strong memory T cells.

domain known as S2 domain, which are major immunogenic targets to induce preventative immune response [4,24]. RBD is contained by the $\mathrm{S} 1$ subunit, which facilitates the virus to bind with the ACE-2 receptor containing cells, and because of this, the S1 subunit became the major target for neutralizing antibodies $[4,25,26]$. Neutralizing antibodies deal with antigen and induce an immune response by $\mathrm{Fc}$ $\gamma$-receptors containing cells [4]. SARS-CoV-2 proteome microarray technology showed that IgG immunoglobulin response against $\mathrm{N}$-protein, S1 protein, ORF9b, and other SARS-CoV-2 proteins were found from recovered individuals [4,27]. Cysteine-like protease of SARS-CoV-2 targeted IgG, IgM, and IgA were found in COVID-19 patients $[4,28]$. Long term study showed that spike protein-specific IgA antibodies appeared promptly and culminated in concentration at 20-22 days. However, the IgM response appeared and elevated at the highest level within 10-12 days and disappeared within 18 days after symptoms onset [4,29]. Several studies showed that among mild COVID-19 patients, RBD specific IgG immunoglobulin waned within two to four months, and specific antibody against N-protein of SARSCoV-2 diminished early. These studies demonstrated that long-term humoral immune response might not be possible [4,30,31]. Extensive research on adaptive immune response suggested that neutralizing antibody is not harmonized with COVID-19 disease severity. It also stipulated that cellular immunity is also an important player to solve SARS-CoV-2 affiliated complexity $[1,4]$.

\section{T Cells Response against Sars-Cov-2 Virus}

$\mathrm{T}$ cell in opposition to SARS-CoV-2 has been recognized $[1,32]$.
According to Weiskopf et al., 2020, a collaborative research team established that ten people are sick enough with novel coronavirus and hospitalized in the I.C.U showed SARS-Cov-2 responsive T cells [23]. Though the infected case and death case are many, the data about $\mathrm{T}$ cells is not enough. Ten out of ten patients showed SARSCoV-2 responsive CD4+ cells, and among ten patients, 8 of them showed SARS-CoV-2 responsive CD8+ cells [23]. The collaborating research team also worked on ten healthy individuals. Interestingly, they found that 2 out of 10 healthy individuals had inadequate SARS-CoV-2 responsive T cells, which may be caused by crossreactivity [23]. Further studies suggested that approximately 28$50 \%$ of people had memory T-cells cross-reactivity against SARSCoV-2 [1,21,33-35]. It may be possible to show cross-reactivity against the SARS-CoV-2 virus because some coronavirus family members have appeared as "common cold" [1]. According to Boyton et al. concerning lymphopenia is an important topic for $\mathrm{T}$ cell immunology of COVID-19 patients. There are many topics such as $\mathrm{T}$ cell deterioration, cytokine program, cytokine storms, focus antigens, epitopes, and the benefaction of viral cross-reactivity, which are compulsory to understand T cell's condition responses in COVID-19 patients [36]. Lymphopenia is commonly observed in cases of severe COVID-19 patients, which is judged by elevated C-Reactive Protein (CRP), D-dimer, and ferritin [36]. Some people show robust, specific $\mathrm{T}$ cell immunity though they lack an antibody and may never have been defined as positive in PCR testing [36]. Helper T cell type $1(\mathrm{Th}-1)$ is the ancestor of SARS-CoV-2 reactive $\mathrm{T}$ cell that promotes cell-arbitrated immune responses needed for 


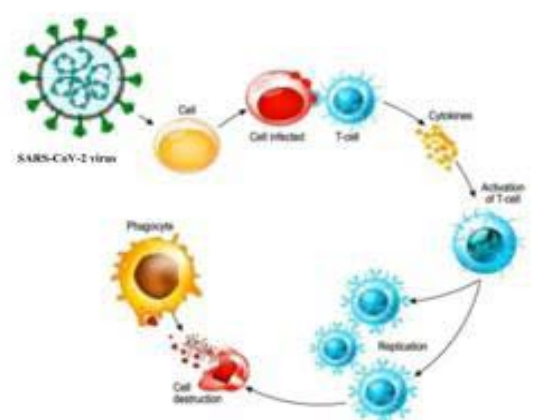

T-cell activation

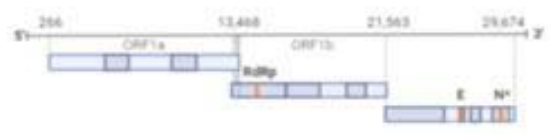

SARS-CoV-2 genome induced by T-cell
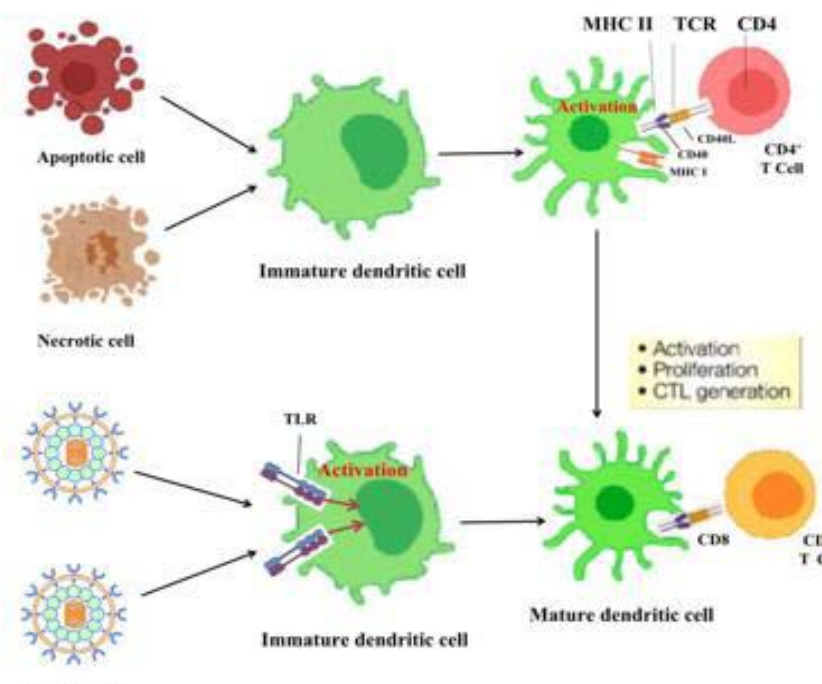

Pathogen

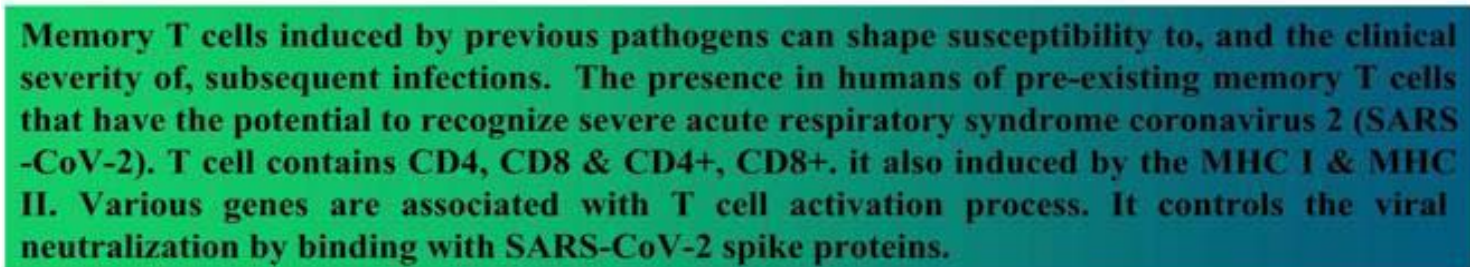

Figure 3: T-cells activation and response to SARS-CoV-2 in infected patients. SARS-CoV-2 attach cell types that contain ACE-2 receptors. Toll-like receptors on A.P.C.s (e.g. Dendritic cells) are the first to recognize pathogens like SARS-CoV-2. After attachment of SARS-CoV-2 to T.L.R.s, immature dendritic cells then activated to mature dendritic cells, followed by cytotoxic T cells. Then cytotoxic T cells destroy infected cells via apoptosis. Helper-T (CD4+) cells preserve memory against SARS-CoV-2 after attaching with mature dendritic cells via TCR-MHC II complex. When the SARS-CoV-2 throw oneself into the host cell via fusion of the membrane, then SARS-CoV-2 delivers its positive single-stranded R.N.A genome toward the cytoplasmic compartment to translate ORF1a and ORF1b into two large polyproteins. After synthesis of glycoprotein E, it integrates with rough endoplasmic reticulum or Golgi membrane. Finally, virus-molecules filled vesicle fused with the cell membrane, and the contemporary virus gets access to infect new healthy cells.

host defense against intracellular viral pathogens. TH-1 cells produce IFN- $\gamma$, IL-2, IL-10, and TNF - $\alpha / \beta[36]$. While conversion of CD8+ $\mathrm{T}$ cells into cytotoxic $\mathrm{T}$ cells happened, then $\mathrm{CD} 4+\mathrm{T}$ cells convert into effector T cells that processed cytokines and chemokines [37]. It is observed that severely ill patients had low CD4+ T cell levels than non-severely ill patients $[37,88]$. A study conducted on 123 patients diagnosed with COVID-19 showed that about $95.24 \%$ of severely ill patients had reduced CD4+ T cells [37,38]. A subclass of CD4+ T cells is Treg (Regulatory $\mathrm{T}$ cells), which can hinder the immune reaction [37]. Scientists found that naive Treg cells (CD45RA+, CD3+, CD4+, $\mathrm{CD} 25+, \mathrm{CD} 127+)$ and persuaded Treg (CD45RO+, CD3+, CD4+, $\mathrm{CD} 25+, \mathrm{CD} 127+$ ) are diminished in critically ill patients $[37,88]$. Furthermore, naive regulatory $\mathrm{T}$ cells notably lessened in critical and moderate individuals [22]. The $\mathrm{T}$ cells response against SARS-CoV-2 schematically presented in Figure 2.

\section{T-Cell Response Induced by Covid-19}

T-cells are potent to give durable immunity. But it is still unclear whether T cells give durable immunity to SARS-CoV-2 or not [39]. Activation and proliferation of CD4+ T cells and CD8+ T cells against SARS-CoV-2 infection are not unique because it happens in most acute viral infections of humans [39] (Figure 3). Among severe COVID-19 patients, some features have been occurred like- a high quantity of systemic cytokines or chemokines, most commonly IL-6, CXCL9,
CXCL8, and CXCL10 [39] or faulty IFN-1 responses, which may alter $\mathrm{T}$ cell responses [40]. Various experimental evidence described T-cell reactions prompted by SARS-CoV-2. Recently, a very effective $\mathrm{T}$-cell response has been found related to the production of higherrated neutralizing antibodies [41]. The antigenic responses of SARSCoV-2 patients produce IgM and IgG antibodies, and a later phase seroconversion has also been seen that is determined by the helper T-cells [41]. Some current research evidence provides information to target the Th1 type response as a key controller for SARS-CoV-2 [41]. Besides, these T-cell responses provide strong cellular immunity that is a key determinant factor for the development of an effective SARS$\mathrm{CoV}-2$ vaccine [41]. Researchers experimented on the SARS-CoV recovered patients for four years, and they confirmed the persistence of memory T-cell. By D.T.H's response and by proliferated T-cell, they performed their function [41]. Whatever, recent reports of SARS-COV-2 indicate that the peripheral blood mononuclear cells of patients contaminated with SARS-CoV-2 virus have shown remarking depletion in the quantity of CD8+ and CD4+ T-cell, which is occurred by the production of compromised memory T-cells and that preserved in SARS-CoV-2 survivors [41] (Figure 3).

\section{T Cells Response of Recovered Patients from Covid-19 Disease}

A recent study shows that SARS-CoV-2 contamination induces 
Table 2: Cytokines profile after SARS-CoV-2 infection.

\begin{tabular}{|c|c|c|c|}
\hline Cytokines/Antibody & Producing cells & SARS-CoV-2 & References \\
\hline IL-1 $\beta$ & Macrophages & Present & [88] \\
\hline $\mathrm{IL}-2$ & Th1 cells & Present & [89] \\
\hline IL-6 & Th2 cells, fibroblasts, macrophages, endothelial cells & Present & [88] \\
\hline IL-18 & Activated T cells, macrophages & Present & [88] \\
\hline TNF- $\alpha$ & Macrophages, T cells & Present & {$[88,89]$} \\
\hline $\lg G$ & & Present & {$[90,91]$} \\
\hline $\lg M$ & & Present & [91] \\
\hline
\end{tabular}

Table 3: Some Vaccine development companies and their racing status against COVID-19.

\begin{tabular}{|c|c|c|}
\hline Developer Company/Institute & Vaccine type [vaccine name] & Current status [Phase/Trial ID] \\
\hline Moderna & mRNA [mRNA-1273] & $\begin{array}{l}\text { Phase } 3 \\
\text { ClinicalTrials.gov Identifier: NCT04470427 }\end{array}$ \\
\hline Astrazeneca and University of Oxford & Viral vector vaccine mainly adenovirus vector vaccine [AZD222] & $\begin{array}{l}\text { Phase } 2 \text { \& } 3 \\
\text { ClinicalTrials.gov Identifier: NCT04400838 }\end{array}$ \\
\hline Novavax & Protein-based vaccine [NVX-CoV2373] & $\begin{array}{l}\text { Phase } 3 \\
\text { ClinicalTrials.gov Identifier: NCT04583995 }\end{array}$ \\
\hline Sinovac & Whole virus vaccine but inactivated [CoronaVac] & $\begin{array}{l}\text { Phase } 3 \\
\text { ClinicalTrials.gov Identifier: NCT04456595 }\end{array}$ \\
\hline University of Pittsburgh & Protein based vaccine [PittCoVacc] & Phase: Preclinical \\
\hline BioNTech, Fosun Pharma and Pfizer & mRNA [BNT162b1] [BNT162b2] & $\begin{array}{l}\text { Phase } 2 \text { \& } 3 \\
\text { ClinicalTrials.gov Identifier: NCT04368728 }\end{array}$ \\
\hline Curevac & mRNA [CVnCoV] & $\begin{array}{l}\text { Phase } 2 \\
\text { ClinicalTrials.gov Identifier: NCT04515147 }\end{array}$ \\
\hline Vaxine & Protein based vaccine [COVAX19] & $\begin{array}{l}\text { Phase } 1 \\
\text { ClinicalTrials.gov Identifier: NCT04453852 }\end{array}$ \\
\hline
\end{tabular}

specific and preventive immunity in recovered individuals from COVID-19 disease compared to healthy unexposed donors [1,23]. Using HLA class 1 and 2 peptides "megapools", 70\% of COVID-19 patients have shown particular CD8+ T cells against SARS-CoV-2 and $100 \%$ of COVID-19 individuals have shown specific CD4+ $\mathrm{T}$ cell against SARS-CoV-2 [1,23]. Insufficient magnitude and durability were the main causes of a failure to develop protective immunity [1] and even developed a high functional vaccine. The neutralizing antibody response depends on the response of CD4+ T cells $[42,43]$. Therefore, it is essential to understand the immensity and the composition of the human CD4+ and CD8+ T cell responses to SARS-CoV-2 [1]. Grifoni et al. 2020 revealed that, by stimulating lymphocytes of the patients who recovered from mild COVID-19 with well-characterized SARS-CoV-2 peptide pools, the virus determinant $\mathrm{CD} 4+\mathrm{T}$ cell reactions were noticed that predominantly targets the spike, $\mathrm{M}$, and $\mathrm{N}$ protein. SARS-CoV-2 determinant CD4+ T cell was identified and quantified in recovered COVID-19 patients by an assay named activation-induced marker (A.I.M) assay [1]. ActivationInduced Marker (AIM) assay is an independent cytokine assay to identify antigen-specific CD4+ T cells [44]. Effective production of interferon (I.F.N)- $\gamma$ besides other cytokines have been observed [1] In terms of $\mathrm{CD} 4+\mathrm{T}$ cell responses, $50 \%$ of $\mathrm{CD} 4+\mathrm{T}$ cell reactions were against the spike(S) protein, and 50\% were against MP [1]. But currently under development, vaccines are made by most companies which aimed at the spike proteins. The clinical explanation shows that severe lung injury is the major clinical property of SARS-CoV-2 infections. Cytokines, chemokines, and immune cells mediated inflammation are the pathophysiological procedures in viral infection (Table 2).

\section{Pipeline of Racing Sars-Cov-2 Vaccines}

In this pandemic situation of the world, vaccination is the best way the prevention SARS-CoV-2. But it might be an overlong process to develop a potent vaccine; at least 18 months may need to develop a potent vaccine with a modern approach and development strategy. More than 165 groups of scientists are working on this vaccination project against the SARS-CoV-2 [45,46]. Safety trials of a vaccine in humans first started in March, though these vaccines' paths are uncertain. There are about 8 ways of vaccination has been used to provoke a response of the immune system against SARS-CoV-2 [10], they are- whole virus vaccine (inactivated or weakened): assembled via non-infectious agent which elicit various viral proteins for identification by immune cells and can be produced substantial amount $[47,48]$. For instance- Sinovac constructed an inactivated COVID-19 vaccine restraining aluminum hydroxide, took part in phase 3 clinical trial [48], viral vector vaccine (replicating or non-replicating): made by adenovirus or lentivirus type carrier virus which conveys pertinent gene mainly spike glycoprotein encoded gene for coronaviruses [48]. The crucial advantage of viral Vector-based vaccine is eliciting immunogenicity up against heterological infections that persuades innate immune reactions, which is indispensable for the adaptive immune responses [48,49]. For instance- CanSino Biological Inc. and Beijing Institute of Biotechnology constructed a Ad5 (Adenovirus type-5) vector vaccine, pre-existing immunity against adenovirus type-5 vector may also impact on $\mathrm{T}$ cell response after vaccination $[48,63]$, nucleic acid vaccine (DNA or mRNA): Spike glycoprotein among coronavirus's other proteins is a most usual contender in mRNA vaccine [48]. Due to high efficacy, fast build-out, the mRNA vaccine is propitious than other typical vaccines [50,51]. For instance, Pfizer and BioNTech constructed an mRNA vaccine (BNT126b1), 
Table 4: Vaccine development strategies with modern technologies.

\begin{tabular}{|c|c|c|c|}
\hline Company/Institute & Development Strategy & Target protein & References \\
\hline Novavax & Recombinant protein nanoparticle technology & Spike (S) glycoprotein & {$[60,66]$} \\
\hline Moderna & mRNA-based vaccine confined with lipid nanoparticle & Spike (S) glycoprotein & {$[61,66]$} \\
\hline Institute of Pasteur & Used measles vaccine as a vector & Spike (S) glycoprotein & {$[66]$} \\
\hline University of Hong Kong & Used weakened version of influenza virus & RBD of spike (S) glycoprotein & {$[66]$} \\
\hline University of Queensland & Molecular clamp technology (Lab created polypeptide) & Spike (S) glycoprotein & {$[66]$} \\
\hline University of Oxford & Adenoviral vaccine vector & Spike (S) glycoprotein & {$[63,66]$} \\
\hline \multirow[b]{2}{*}{ Shenzhen Geno-Immune Medical Institute } & Lentiviral vector system & Spike (S) glycoprotein & \multirow[b]{2}{*}[66]{} \\
\hline & $\begin{array}{ll} & \text { Modified antigen-presenting cells against COVID-19. } \\
\text { - } & \text { Modified dendritic cells }\end{array}$ & Spike (S) glycoprotein & \\
\hline CanSino Biologics & The recombinant adenovirus vaccine candidate & RBD of spike (S) glycoprotein & {$[63,66]$} \\
\hline University of Pittsburgh & Microneedle array with biodegradable needles & Spike (S) glycoprotein & {$[64,66]$} \\
\hline $\begin{array}{l}\text { DukeNUS Medical School \& Arcturus } \\
\text { Therapeutics }\end{array}$ & Self-replicating RNA-based therapeutic vaccine & Spike (S) glycoprotein & {$[65,66]$} \\
\hline
\end{tabular}

which induce an immune response against the receptor-binding domain of S protein [48]. D.N.A vaccine induce T cell and ameliorate antibody production in individuals. Plasmid D.N.A has very good biocompatibility and is cost-effective for production [48,52]. For instance-Inovio Pharmaceuticals constructed a D.N.A vaccine against the SARS-CoV-2 virus [54]. Protein-based vaccine (protein subunit or virus-like particles): They are viral proteins that are likely to induce effective immune responses but not elicit the immunogen's full immunogenic complexity [48]. But in some instances deranged immune responses occurred $[48,53]$; more data are tabulated in Table 3.

Hijacking Host Cells by Sars-Cov-2 \& the Ultimate Target Proteins for an Ideal Vaccine

Initially, the SARS-CoV-2 virus spreads through the droplets or aerosols from infected individuals [55]. The virus sometimes uses its spike glycoprotein to enter the host cells via the ACE-2 receptor [55]. When spike proteins attach with the cell's ACE-2 receptor, then TMPRSS-2, a type of protease, cleaves the viral spike proteins to accelerate the amalgamation of the virus and the host cell [56]. The virus enters into the host cells through endocytosis [55]. Positive ssRNA is released into the cytoplasm, and then the main work begins by hijacking the cell [55]. By the translation process, viral R.N.A.s produce viral proteins like Nucleocapsid (N), Membrane (M), Envelope (E), and Spike (S) proteins [55]. After releasing viral particles, the particles infect type-2 pneumocytes and enterocytes of the G.I. tract $[55,57,58]$. The ultimate targets of vaccine candidates are to make antibodies that inhibit attachment with the ACE-2 receptor. $S$ glycoproteins attach with ACE-2 receptor-like "lock and key" to invade into the cell, so the antibodies produced after vaccination mainly target $S$ proteins [59]. S protein conveys a type of epitope that can bind with B-cell. S protein is responsible for viral infection, and also it induces immune response with neutralizing antibodies [59]; for more details about ultimate target proteins for an ideal vaccine, follow (Table 4).

\section{Potential Clinical Trial Data of Current Vaccines of Covid-19}

Recently a paper has been published in The New England
Journal of Medicine by the scientists of Moderna Inc. In NEJM, they published their vaccine's human clinical trial phase 1 [ClinicalTrials. gov Identifier: NCT04283461]. Moderna deployed the vaccine trial first with an emerging mRNA-based vaccine. The mRNA-1273 vaccine is a vaccine that is confined to lipid nanoparticles [61]. The lipid nanoparticle encoded capsule is made up of four lipids [61]. These lipids are used in a specific ratio with mRNA to develop the vaccine [61]. Among 45 healthy individuals-22, persons were male, and 23 were female, included in the phase [61]. Ages of 45 healthy adults were between 18-55 years old, received two doses of vaccination 28 days apart, mRNA-1273 vaccination doses were $25 \mu \mathrm{g}$, $100 \mu \mathrm{g}$ and $250 \mu \mathrm{g}$ given to each 15 participants group. It showed that higher antibody responses occurred with higher doses [61]. But it showed some side effects, such as headaches, extreme tiredness, feverish, muscle ache, and ache in the injection site, and it showed mostly usual after $2^{\text {nd }}$ vaccination [61]. Though this vaccine passed phase 1 without any obstacle except some side effects, it needs to go through a more sensible process for further advancement and CD4 $\mathrm{T}$ cell responses were shown after the first vaccination with $25 \mu \mathrm{g}$ and $100 \mu g$ doses [61], whereas CD8 T cell reactions were also shown at a small level after $2^{\text {nd }}$ vaccination with $100 \mu \mathrm{g}$ doses [61].

Another group of scientists from the University of Oxford developed a vaccine for COVID-19 named "AZD222". On July 20, 2020, they published preliminary data of a phase $1 / 2$ [ClinicalTrials.gov Identifier: NCT04400838] about the protection and immunogenicity rate of their vaccine "AZD222" (previously known as ChAdOx1 nCoV-19) in The Lancet. They used chimpanzee adenovirus as a vector in their vaccine, which expressed SARS-CoV-2 spike protein [62]. ChAdOx1 nCoV-19 was given to the test group, and the meningococcal conjugate vaccine (MenACWY) was given to the control group [62]. Each healthy adult aged between 18-55 years received a definite number of viral particles $(5 \times 1010)$ at a dose of ChAdOx1 nCoV-19 vaccine [62]. Ten of the total participants $(n=1077)$ received a booster dose 28 days apart from the first dose of vaccination A multiplexed immunoassay consists of three assays, they are: a) $50 \%$ plaque reduction assay; b) a microneutralization assay; c) a pseudovirus neutralization assay. These three assays were weighed total IgG in humoral responses [62]. Cellular responses were weighed by an assay named ex-vivo interferon- $\gamma$ enzyme-linked immunospot assay [62]. Local and systemic side effects appeared in 


\begin{tabular}{|c|c|c|c|c|c|}
\hline $\begin{array}{c}\text { Company } \\
\text { name }\end{array}$ & Vaccine name & $\begin{array}{l}\text { Vaccine } \\
\text { type }\end{array}$ & Mechanism & $\begin{array}{c}\text { Number of } \\
\text { participants }\end{array}$ & Reference \\
\hline $\begin{array}{l}\text { Moderna \& } \\
\text { NIAID }\end{array}$ & mRNA-1273 & mRNA & $\begin{array}{l}\text { Encodes S-2P antigen, which is composed of SARS-CoV-2 } \\
\text { glycoprotein with transmembrane anchor and S1-S2 cleavage site. } \\
\text { Two following proline replacement stabilized S-2P. }\end{array}$ & 30,000 participants & $\begin{array}{l}\text { [https://clinicaltrials. } \\
\text { gov/ct2/show/ } \\
\text { NCT04470427], [61] }\end{array}$ \\
\hline $\begin{array}{l}\text { BioNTech, } \\
\text { Pfizer \& } \\
\text { Fosun } \\
\text { Pharma }\end{array}$ & $\begin{array}{l}\text { BNT162b1 and } \\
\text { BNT162b2 }\end{array}$ & mRNA & $\begin{array}{l}\text { These vaccines are nucleoside modified R.N.A. vaccines composed } \\
\text { of RBD domain antigen and T4 fibritin-obtained "foldon" trimerization } \\
\text { domain (to increase immunogenicity). }\end{array}$ & $\begin{array}{l}\text { Estimated about } \\
29,481 \text { participants }\end{array}$ & $\begin{array}{l}\text { [https://clinicaltrials. } \\
\text { gov/ct2/show/ } \\
\text { NCT04368728], [92] }\end{array}$ \\
\hline $\begin{array}{l}\text { CanSino } \\
\text { Biologics }\end{array}$ & Ad5-nCOV & $\begin{array}{l}\text { Viral-vector } \\
\text { vaccine }\end{array}$ & $\begin{array}{l}\text { This vaccine used weak non-replicating E1, and E3 deleted Adenovirus } \\
\text { as a vector which expresses S-glycoprotein of SARS CoV-2. Tissue } \\
\text { plasminogen activator signal peptide gene used to escalation full- } \\
\text { length spike gene based on Wuhan-Hu-1. }\end{array}$ & $\begin{array}{l}\text { Will enroll } \\
\text { approximately } \\
5,000 \text { participants } \\
\text { in Saudi Arabia }\end{array}$ & $\begin{array}{l}\text { [https://www. } \\
\text { clinicaltrialsarena.com/ } \\
\text { news/cansino-vaccine- } \\
\text { saudi-trial/], [63] }\end{array}$ \\
\hline $\begin{array}{l}\text { University } \\
\text { of Oxford \& } \\
\text { AstraZeneca }\end{array}$ & $\begin{array}{l}\text { AZD222 } \\
\text { (previously } \\
\text { known as } \\
\text { ChAdOx1nCoV-19) }\end{array}$ & $\begin{array}{l}\text { Viral-vector } \\
\text { vaccine }\end{array}$ & $\begin{array}{l}\text { This vaccine composed of replication-impaired simian adenovirus } \\
\text { vector ChAdOx1 and full length of surface spike glycoprotein of SARS- } \\
\text { CoV-2 virus with tissue plasminogen activator leader sequence. }\end{array}$ & $\begin{array}{l}\text { Estimated about } \\
10260 \text { participants }\end{array}$ & $\begin{array}{l}\text { [https://clinicaltrials. } \\
\text { gov/ct2/show/ } \\
\text { NCT04400838], [62] }\end{array}$ \\
\hline Sinovac & CoronaVac & $\begin{array}{l}\text { Whole } \\
\text { inactivated } \\
\text { virus } \\
\text { vaccine }\end{array}$ & $\begin{array}{l}\text { Among } 11 \text { strains Sinovac research team chose the CN2 strain } \\
\text { because it has magnificent genetic stability without spike protein } \\
\text { alteration. To inactivate the virus, } \beta \text {-propiolactone has been used. }\end{array}$ & $\begin{array}{l}\text { About } 8870 \\
\text { participants }\end{array}$ & $\begin{array}{l}\text { [https://clinicaltrials. } \\
\text { gov/ct2/show/ } \\
\text { NCT04456595], [93] }\end{array}$ \\
\hline
\end{tabular}

the ChAdOx1nCoV-19 group, including pain, chills, muscle ache, headache, malaise, and feverish, which were alleviated by paracetamol [62]. Since this vaccine's main target is to produce antibodies against SARS-CoV-2 spike protein and spike protein, definite $\mathrm{T}$-cell responses were produced by the ChAdOx1nCoV-19 group, which was picked on day 14 after the first dose of vaccination and were boosted further after the second vaccination [62]. After proving the protection rate and immunogenicity rate, this $\mathrm{ChAdOx} n \mathrm{CoV}-19$ vaccine goes to the phase- 3 of the trial.

Chinese vaccine company CanSino Biologics made a recombinant adenovirus type-5 (Ad5) vectored SARS-CoV-2 vaccine and conducted the phase-1 trial [ClinicalTrials.gov Identifier: NCT04313127] in Wuhan, China [63]. $5 \times 1010$ viral particles per $0.5 \mathrm{~mL}$ to low dose group, $1 \times 1011$ viral particles per $1 \mathrm{~mL}$ to middle dose group, and $1.5 \times 1011$ viral particles per $1.5 \mathrm{~mL}$ to high dose group were given via intramuscular injection of the vaccine [63]. The participants who enrolled in the trial were healthy, and they aged between 18 to 60 years of age, and the side effects after vaccination appeared in seven days [63]. Specific antibodies were tested by ELISA, neutralizing antibody tested by SARS-CoV-2 virus neutralization, and pseudovirus neutralization tests [63]. T-cell responses were determined by two assays, they are- enzyme-linked immunospot assay and flow-cytometry assay, and 108 out of 195 individuals were selected for the trial [63]. The average age of 108 individuals was 36.3 years [63]. Some side effects showed within the first seven days after vaccination among each group [63]. The most common local adverse effects were pain at the injection site, and besides, systemic effects also showed after immunization. They are- fever, fatigue, headache, and muscle pain, but the effects were mild or moderate [63]. Neutralizing antibodies started to increase within 14 days after vaccination, and the level of antibodies was at the pick after 28 days of vaccination [63]. However, specific T-cell responses after vaccination increased on day 28; a slight decrease in the T-cell response happened [63]. After the immunization, IFN- $\gamma$ was found from CD4+ and CD8+ cells by day 14 and 28 among all participants [63]. More investigation will follow up through the current phase-2 [ClinicalTrials.gov Identifier: NCT04341389] trial in China [63].

A group of scientists from the University of Pittsburgh targeted the coronavirus Spike (S) protein as a key component for vaccines to prevent the coronavirus infection. They addressed their SARS-CoV-2 vaccine as "PittCoVacc." Previously they worked on MERS-CoV vaccines in a preclinical study using dissolved microneedle arrays (M.N.A.s), which were given intracutaneously [64]. They constructed a trimeric design where codon-optimized MERS-1 subunit vaccines were combined with a fold on the trimerization domain to emulate the indigenous viral composition [64]. Previously they showed that MNAdelivered MERS-CoV vaccines elicited promising immunogenicity in clinical trials [64]. Because of urgent needed SARS CoV-2 vaccines, they applied their previous experience on M.N.A.s strategy to develop a potent and novel vaccine [64]. Researchers planned and assembled a microneedle array-based SARS-CoV-2-S1 and SARS-CoV-2S1fRS09 subunit vaccines in just four weeks after finding the sequence of the S1 subunit of SARS-CoV-2 [64]. These vaccines showed potent antibodies against particular antigen after two weeks of immunization [64]. They aimed to deliver the vaccine via skin because the skin might be a fundamental aim for immunization as skin restrains a wide variety of A.P.C.s and immune accessory cells [64]. Sera from mice were collected at $23^{\text {rd }}$ week and $55^{\text {th }}$ week to assess the existence of IgG antibody against MERS-S1 by ELISA [64]. The IgG antibody level was measured at week 6; interestingly at week 23, the IgG levels increased and sustained through week 55 [64]. According to those promising results against MERS-CoV, it was expected that this M.N.A based SARS-CoV-2-S1 and SARS-CoV-2-S1fRS09 subunit vaccine act potentially against the SARS-CoV-2 virus [64]. At weeks $1,2,3$ and 4, sera were collected from mice to evaluate the existence of SARS-CoV-2 determined IgG antibody [64]. In the second week, IgG feedback was detected [64]. Further advancement is going on, needs more sophisticated research to estimate the efficacy and potency of this vaccine (Table 5 )

\section{Declining Quantity of Antibody Durabilitity of Cd4+, Cd8+ Cells}

Developing a potently neutralizing antibody is the main focus of most vaccine candidates. PCR is used to identify SARS-CoV-2 R.N.A [21]. Helper T cell and production of neutralizing antibodies are interconnected [21]. Among two designed peptide pools, the first peptide pool S-1 spanned the N-terminal part [21]. The second 
Table 6: Animal model strategies for SARS-CoV-2 vaccines development.

\begin{tabular}{|c|c|c|c|}
\hline Animal & Advantages & Disadvantages & References \\
\hline Rhesus macaques & $\begin{array}{l}\text { - Satisfactory model for vaccine and therapeutic studies } \\
\text { against SARS-CoV-2. }\end{array}$ & $\begin{array}{l}-\quad \text { Short sample size. } \\
\text { - } \quad \text { Temporary clinical signs. }\end{array}$ & {$[94,95]$} \\
\hline Macaca fascicularis & $\begin{array}{l}\text { Mimicking progression and severity of COVID-19 } \\
\text { adjacent to clinical disease. }\end{array}$ & $\begin{array}{l}\text { The quantity of viral R.N.A is short, } \\
\text { expensive. }\end{array}$ & [96] \\
\hline $\begin{array}{l}\text { Transgenic hACE2 } \\
\text { mice }\end{array}$ & $\begin{array}{l}\text { - } \quad \text { Satisfied Koch's postulates. } \\
\text { - Cooperative in the progression of vaccines. }\end{array}$ & $\begin{array}{l}-\quad \text { Low amount of supply. } \\
\text { Expensive. } \\
\text { - } \quad \text { Show moderate inflammatory responses } \\
\text { - Lung damage. }\end{array}$ & {$[57]$} \\
\hline BALB/c mice & $\begin{array}{ll}- & \text { Economic } \\
\text { - } & \text { Suitable and easy breeding } \\
\text { - } & \text { They are efficiently used for in vivo study of vaccines. }\end{array}$ & - $\quad$ Showed mild inflammatory responses. & {$[97]$} \\
\hline $\begin{array}{l}\text { Golden Syrian } \\
\text { hamster }\end{array}$ & $\begin{array}{l}\text { - Freely accessible } \\
\text { Good choice to study pathogenesis of COVID-19 and } \\
\text { vaccines. }\end{array}$ & $\begin{array}{l}\text { - Only evaluated mRNA of the hamster's } \\
\text { cytokine profiles. }\end{array}$ & {$[20,34]$} \\
\hline
\end{tabular}

peptide pool, S-2, covered the C-terminal portion [21]. RBD of the S-1 subunit was the crucial target of the counteracting antibody [21]. According to Braun et al., the researchers found that 24 of 68 (35\%) healthy individuals and $83 \%$ of COVID-19 patients had SARS-CoV-2 S-2 sensitive CD4+ T cells. Among all healthy individuals, only 5.8\% showed S-1 sensitive CD4+ T cells [21]. These 24 healthy donors and 6 out of 24 RHD has S-1 reactive CD4+ T cell [21]. All healthy donors were IgG negative for S-1 in contrast to patients [21]. In both patients and RHD, S-2 sensitive CD4+ T cells expressed I.F.N- $\gamma$. The expressing I.F.N- $\gamma$ were similar in patients and RHD [21]. S-2 reactive I.F.N- $\gamma$ and CD4+ T cells from RHD displayed co-expression TNF- $\alpha$ patterns whereas S-2 reactive I.F.N- $\gamma$ and CD4+ T cell from patients displayed heterogenous TNF- $a$ expression patterns [21]. It demonstrates S-sensitive CD4+ T cells are present in COVID-19 patients and unexposed healthy donors [21]. Both N-terminal (S1 ) and C-terminal (S-2) of spike glycoprotein were targeted by $S$ sensitive CD4+ T cell, which was collected from COVID-19 patients [21]. While S-2 was strongly targeted by S sensitive CD4+ T cells from RHD, it exhibits higher reactivity to other human "Common Cold" coronaviruses (HCoVs)229E and OC43 than S-1 [21] Numbers of S (cross) sensitive CD4+ T cells in RHD have not been generated very recently because it was not match up with the number of antibodies against $\mathrm{HCoVs}$ and the pre-existing S-cross sensitive CD4+ T cell has a defensive role in SARS-CoV-2 infection [21].

\section{The Challenges of Covid-19 Vaccines}

The vaccine development race is moving so fast. But development is not at all. To make an ideal vaccine, we need to focus on Safety and efficacy $[55,66]$. However, previous SARS-CoV and MERS$\mathrm{CoV}$ vaccine development experiences give speed to the design and development of SARS-CoV-2 vaccines $[55,66]$. Unfortunately, we know little yet about the protective immune response to SARSCoV-2 [67]. So, we have to look intensively at immunological response challenges like Antibody-Dependent Enhancement (ADE), inflammation and severity $[55,67]$. The major challenges aredurability of protection, and the chance of re-infection is still unclear [67]. The preliminary target is a high level of Safety for a universally used vaccine [67]. Some clinical trial data of vaccines reported against the SARS-CoV-2 virus showed promising results by inducing a robust antibody response besides $\mathrm{T}$ cell response. However, it still not known how much time these vaccines can give protection.

\section{Antibody-dependent enhancement}

Antibody-Dependent Enhancement (ADE) is a phenomenon where non-neutralizing antibodies enhance the pathogenesis of a virus. Unnecessary attachment of viruses with cells that are generally impermeable for viruses is promoted by A.D.E [68]. In vitro study showed that A.D.E increased the entry of viruses via $\mathrm{F} c \gamma$-Receptor $(\mathrm{F} c \gamma \mathrm{R})$ in leu of viral receptor-arbitrated entry [68]. Some earlier studies showed that IgG antibodies against the spike glycoproteins of SARS-CoV and MERS-CoV enhance viral pathogenesis through A.D.E [68]. A.D.E has developed an established concept about A.D.E in the Dengue virus; even formalin-mollified vaccines against respiratory syncytial virus and measles have been documented A.D.E cases [4,68-71]. IgG antibodies from departed individuals were collected and transferred those antibodies to SARS-CoV affected non-human primates showed acute lung injury [72]. So, this phenomenon should be considered seriously in the context of developing COVID-19 vaccines. Inducing poor quality antibodies may one of the reasons for failure for vaccine candidates [73]. However, A.D.E has not happened yet among limited data for vaccines against SARS-CoV-2 [73].

\section{Difficulty with a SARS-CoV-2 animal challenge model}

An ideal animal model is an urgent need for evaluating underlying mechanisms, potential vaccines, and therapeutic strategies $[74,75]$. To evaluate coronavirus disease progression and replication, not all animal models provide humans' closest characteristics $[61,76]$. So, to determine the COVID-19 vaccine efficacy and therapeutic strategies, suitable animal models like non-human primates, mice will be the best options. Some animal models of SARS-CoV-2 and their advantages, disadvantages are stated in Table 6.

Usually, vaccine development takes ten to fifteen years, but now pharmaceutical companies concise time within fifteen to eighteen months [77], which brings some more challenges, for instances:

- Integrated phase trials entailed small-scale people, uncertainty when the vaccine is publicly available [77]. Unknown side effects may occur when the vaccine is given at a large scale; if not, age, sex, comorbidities are not perceived [77,78].

- Previously there are no successful outcomes available on mRNA or D.N.A. vaccine platforms, even mRNA vaccine delivered via lipid nanoparticle, which requires the low temperature to preserve. Thus mRNA vaccine scaling up manufacturing yet to be determined $[77,79]$.

- $\quad$ Electroporation or vaccine transport devices are known as safe strategies. But overall, the vaccine delivery system is complicated $[77,80]$. 
- $\quad$ CanSino Biologics developed a vaccine against COVID-19 by using the Adenovirus type 5 vector. But the main concern is that pre-existing immunity against Adenovirus may alleviate this vaccine's potentiality $[63,77,81]$.

- The fast and broad-scale production of vaccines is quite challenging, and global requirements yet unpredictable [77].

- Virus mutation may assuage vaccine efficacy $[77,82,83]$.

\section{Policy Challenges to Clinical Trials}

The clinical trial is a part of research investigations. People volunteer themselves to test new vaccines, drugs, or other new treatments to prevent or treat various diseases. But most of the time, clinical trials fail to achieve the goal, which is how the drawback of research increased in the mid-period of the pandemic. An outbreak like COVID-19 needs speed and effective analysis. But unfortunately, "field test" of vaccine potentiality and efficacy need a rising number of infections because, at the initial stage of infection, it may take a long time to examine the efficacy and potency of a vaccine. Everyone needs a balance between rescue lives and doing research. In a pandemic situation, the first preference is to rescue life, but the unavoidable limitations of preventive measures make it tough to tackle. During human challenge studies, participants are deliberately infected from low virulence coronavirus strains to pandemic influenza virus $\mathrm{H} 1 \mathrm{~N} 1$ to test vaccines' efficacy or therapeutics [84]. Though good Safety is maintained in the challenge study, some serious harms in the influenza challenge study were observed [84].

To select potent vaccine candidates, human challenge studies need to accelerate vaccine development by providing public health benefits in smaller, shorter, and less expensive way than other types of therapeutic studies [84]. Nevertheless, ethical issues push up some arguable and unsolved points in research ethics [84]. Some trial policies may increase a healthy individual's risk and may bring risks of spreading pathogens to others if the pathogen is used as a Vector or agent [84].

Community faith can be a major issue during epidemics and pandemics [84]. Human challenge study policies should belong to the highly scientific procedure, and a high level of ethical procedure should be maintained strongly to protect individuals of studies [84]. Working with the infection of novel diseases with high-level unpredictability may increase clinical trials' challenges. It is also important that the rate of the unpredictability of known pathogens may higher than they seem [84]. The worst outcomes happened recently on the dengue virus vaccine trial; a few volunteers died because of vaccine-enhanced disease severity [85].

\section{Future Perspective and Challenges}

In this setting, painstakingly design human trials that build up and screen wellbeing and characterize corresponds and sturdiness of protection, may not just outcome in a powerful countermeasure that diminishes the pandemic yet additionally give key robotic replies into safe control of SARS-CoV-2 disease and conceivably related profoundly pathogenic coronaviruses that could develop later on [8]. New vaccines strategies should apprise to increase T cell reaction to facilitate long-lasting memory. Increasing systemic and tissueresident memory T cells might be a convenient strategy [6]. Molecular mapping will include the significant definite goal of the human coronavirus-specific $\mathrm{T}$ cell responses [1]. Besides, some researchers already concluded that Tinospora crispa as potential COVID-19 M pro inhibitors by isolating their bioactive phytocompounds [86]; and one the other hand, strongest immunogenic epitopes (WTAGAAAYY and GAAAYYVGY) of the S.G.P. for both B cells and $\mathrm{T}$ cells including $\mathrm{CD} 4+\mathrm{T}$-cell epitopes and $\mathrm{B}$-cell epitopes will be the prospective vaccine candidates against SARS-CoV-2 [87].

\section{Conclusion}

Researchers worldwide began working on COVID-19 vaccines development since SARS-CoV-2 outbreaks, but their efforts can still not turn into possible outcomes. The recent coronavirus pandemic, COVID-19 outbreak, appears much broader than other epidemics during the last two decades. This is why many research groups and companies are undertaking efforts to develop an effective vaccine against SARS-CoV-2 all over the world, and developing a potential vaccine to turn into human trial is the most worrisome challenges in the field of vaccine development. Besides antibody analysis, it is important to analyze $\mathrm{T}$ cells functions parallelly. Antibody diminished very early, and memory $\mathrm{T}$ cells had more durability. Researchers tried to find a vaccine that will produce neutralizing antibody and more durable $\mathrm{T}$ cells effect by doing an extensive study on $\mathrm{B}$ cell and $\mathrm{T}$ cell simultaneously. It is not clear that $\mathrm{T}$ cells act either protective or pathogenic because several researchers executed that CD4+ and CD8+ T cells found in asymptomatic COVID-19 exposed people to I.C.U. admitted people. The Strongest T cell response showed in severely ill patients because long term viral load brought long term $\mathrm{T}$ cell priming. From the beginning of the pandemic to now conduct many studies about COVID-19 immunology, some major questions should be considered to make an ideal vaccine that will stimulate antibodies and give long-term effects. More studies on $\mathrm{T}$ cells should be conducted, whether it is protective or not. People exposed to the SARS-CoV-2 virus how long-lasting T cell response, is it protective that antibody diminishes? Which the various vaccine candidates will produce grades of T cells? The vaccine's response to immunocompromised people is still unclear, so it's very urgent to do an extensive study on it. Yet, there is a lot of immunological paradox that remains unsolved. Individual people respond in different ways against COVID-19. Why is this happening? To solve the mystery, further study on $\mathrm{T}$ cell-based immunity is needed to observe whether those vaccines give long term protection or not. The various vaccine candidates produce these grades of $\mathrm{T}$ cells. However, there is no effective therapy for severe COVID-19; therefore, developing an effective vaccine and enhancing the immune response might be considered to prevent SARS-CoV-2.

\section{References}

1. Grifoni A, Weiskopf D, Ramirez SI, Mateus J, Dan JM, Moderbacher CR, et al. Targets of $\mathrm{T}$ cell responses to SARS-CoV-2 coronavirus in humans with COVID-19 disease and unexposed individuals. Cell. 2020; 181: 1489-1501. e15.

2. Zhang J, Zeng H, Gu J, Li H, Zheng L, Zou Q. Progress and prospects on vaccine development against SARS-CoV-2. Vaccines. 2020; 8: 153.

3. Rogers TF, Zhao F, Huang D, Beutler N, Burns A, He W, et al. Isolation of potent SARS-CoV-2 neutralizing antibodies and protection from disease in a small animal model. Science 2020; 369: 956-963.

4. Poland GA, Ovsyannikova IG \& Kennedy RB. SARS-CoV-2 immunity: review 
and applications to phase 3 vaccine candidates. Lancet (London, England). 2020; 396: 1595-1606.

5. Yanchun P, Alexander JM, Guihai L, Xuan Y, Zixi Y, Danning D, et al. Broad and Strong Memory CD4 and CD8 T Cells Induced by SARS-CoV-2 in U.K. Convalescent COVID-19 Patients. bioRxiv: the preprint server for biology. 2020.

6. Channappanavar R, Perlman S. Evaluation of activation and inflammatory activity of myeloid cells during pathogenic human coronavirus infection. MERS Coronavirus: Springer. 2020; 2099: 195-204.

7. Shi Y, Wang N, Zou QM. Progress and challenge of vaccine development against 2019 novel coronavirus (2019-nCoV). Chung Hua Yu Fang I Hsueh Tsa Chih. 2020; 54: E029.

8. Diamond MS, Pierson TC. The challenges of vaccine development against a new virus during a pandemic. Cell Host \& Microbe. 2020; 27: 699-703.

9. Chen W. Promise and challenges in the development of COVID-19 vaccines. Human Vaccines \& Immunotherapeutics. 2020; 16: 2604-2608.

10. Callaway E. The race for coronavirus vaccines: a graphical guide. Nature 2020; 580: 576-577.

11. Rehman M, Tauseef I, Aalia B, Shah SH, Junaid M, Haleem KS. Therapeutic and vaccine strategies against SARS-CoV-2: past, present and future. Future Virology. 2020; 15: 471-482.

12. Song Z, Xu Y, Bao L, Zhang L, Yu P, Qu Y, et al. From SARS to MERS, Thrusting Coronaviruses into the Spotlight. Viruses. 2019; 11: 59.

13. Dagotto G, Yu J \& Barouch DH. Approaches and Challenges in SARS-CoV-2 Vaccine Development. Cell host \& microbe. 2020; 28: 364-370.

14. Tseng C, Sbrana E, Iwata-Yoshikawa N, Newman PC, Garron T, Atmar RL, et al. Immunization with SARS coronavirus vaccines leads to pulmonary immunopathology on challenge with the SARS virus. PloS one. 2012; 7 : e35421.

15. Quan-Xin L, Xiao-Jun T, Qiu-Lin S, Qin L, Hai-Jun D, Jun Y, et al. Clinical and immunological assessment of asymptomatic SARS-CoV-2 infections. Nat Med. 2020; 26: 1200-1204.

16. Lee S, Kim T, Lee E, et al. Clinical Course and Molecular Viral Shedding Among Asymptomatic and Symptomatic Patients With SARS-CoV-2 Infection in a Community Treatment Center in the Republic of Korea. JAMA Intern Med. 2020; 180: 1-6.

17. Jung CY, Park H, Kim DW, Choi YJ, Kim SW \& Chang TI. Clinical Characteristics of Asymptomatic Patients with COVID-19: A Nationwide Cohort Study in South Korea. International journal of infectious diseases: IJID: official publication of the International Society for Infectious Diseases. 2020; 99: 266-268.

18. Weitz JS, Beckett SJ, Coenen AR, Demory D, Dominguez-Mirazo M, Dushof $\mathrm{J}$, et al. Modeling shield immunity to reduce COVID-19 epidemic spread. Nat Med. 2020; 26: 849-854.

19. Cao W, Liu W, Zhang P, Zhang F, Richardus JH. Disappearance of antibodies to SARS-associated coronavirus after recovery. N Engl J Med. 2007; 357: 1162-1163.

20. Choe PG, Perera R, Park WB, Song K, Bang JH, Kim ES, et al. MERS CoV antibody responses 1 year after symptom onset, South Korea, 2015. Emerging infectious diseases. 2017; 23: 1079.

21. Braun J, Loyal L, Frentsch M, Wendisch D, Georg P, Kurth F, et al. SARSCoV-2-reactive T cells in healthy donors and patients with COVID-19. Nature. 2020.

22. Chen G, Wu D, Guo W, Cao Y, Huang D, Wang H, et al. Clinical and immunological features of severe and moderate coronavirus disease. 2019. J Clin Invest. 2020; 130: 2620-2629.

23. Weiskopf D, Schmitz KS, Raadsen MP, Grifoni A, Okba N, Endeman H, et al Phenotype and kinetics of SARS-CoV-2-specific T cells in COVID-19 patients with acute respiratory distress syndrome. Science immunology. 2020; 5 : eabd2071.
24. Ou X, Liu Y, Lei X, Li P, Mi D, Ren L, et al. Characterization of spike glycoprotein of SARS-CoV-2 on virus entry and its immune cross-reactivity with SARS-CoV. Nature communications. 2020; 11: 1620.

25. Wong SK, Li W, Moore MJ, Choe H \& Farzan M. A 193-amino acid fragment of the SARS coronavirus $S$ protein efficiently binds angiotensin-converting enzyme 2. The Journal of biological chemistry. 2004; 279: 3197-3201.

26. Tai W, He L, Zhang X, Pu J, Voronin D, Jiang S, et al. Characterization of the receptor-binding domain (RBD) of 2019 novel coronavirus: implication for development of RBD protein as a viral attachment inhibitor and vaccine. Cellular \& molecular immunology. 2020; 17: 613-620.

27. Jiang $\mathrm{H}$, Li $\mathrm{Y}$, Zhang $\mathrm{H}$, et al. SARS-CoV-2 proteome microarray for global profiling of COVID-19 specific IgG and IgM responses. Nat Commun. 2020 11: 3581.

28. Sanchez-Cerrillo I, Landete P, Aldave B, Sanchez-Alonso S, Sanchez-Azofra A, Marcos-Jimenez A, et al. Differential Redistribution of Activated Monocyte and Dendritic Cell Subsets to the Lung Associates with Severity of COVID-19. medRxiv: the preprint server for health sciences. 2020.

29. Padoan A, Sciacovelli L, Basso D, Negrini D, Zuin S, Cosma C, et al. IgA-Ab response to spike glycoprotein of SARS-CoV-2 in patients with COVID-19: A longitudinal study. Clinica chimica acta; international journal of clinical chemistry. 2020; 507: 164-166.

30. Ibarrondo FJ, Fulcher JA, Goodman-Meza D, Elliott J, Hofmann C, Hausner MA, et al. Rapid Decay of Anti-SARS-CoV-2 Antibodies in Persons with Mild Covid-19. The New England journal of medicine. 2020; 383: 1085-1087.

31. Röltgen K, Wirz OF, Stevens BA, Powell AE, Hogan CA, Najeeb J, et al. SARS-CoV-2 Antibody Responses Correlate with Resolution of RNAemia But Are Short-Lived in Patients with Mild Illness. medRxiv: the preprint server for health sciences. 2020.

32. Ni L, Ye F, Cheng ML, Feng Y, Deng YQ, Zhao H, et al. Detection of SARSCoV-2-Specific Humoral and Cellular Immunity in COVID-19 Convalescent Individuals. Immunity. 2020; 52: 971-977.e3.

33. Mateus J, Grifoni A, Tarke A, Sidney J, Ramirez SI, Dan JM, et al. Selective and cross-reactive SARS-CoV-2 $\mathrm{T}$ cell epitopes in unexposed humans. Science (New York, N.Y.). 2020; 370: 89-94.

34. Le Bert N, Tan AT, Kunasegaran K, Tham C, Hafezi M, Chia A, et al. SARSCoV-2-specific $T$ cell immunity in cases of COVID-19 and SARS, and uninfected controls. Nature. 2020; 584: 457-462.

35. Lipsitch M, Grad YH, Sette A \& Crotty S. Cross-reactive memory T cells and herd immunity to SARS-CoV-2. Nature reviews. Immunology. 2020; 20: 709713

36. Altmann DM, Boyton RJ. SARS-CoV-2 T cell immunity: Specificity, function, durability, and role in protection. Science immunology. 2020; 5.

37. Liu Liana, Xu Linga, Lin Chenb. T cell response in patients with COVID-19. Blood Science. 2020; 2: 76-78.

38. Wan S, Yi Q, Fan S, et al. Characteristics of lymphocyte subsets and cytokines in peripheral blood of 123 hospitalized patients with 2019 novel coronavirus pneumonia (NCP). medRxiv. 2020

39. Chen Z, Wherry EJ. T cell responses in patients with COVID-19. Nature Reviews Immunology. 2020; 20: 529-536.

40. Blanco-Melo D, Nilsson-Payant BE, Liu W, Uhl S, Hoagland D, Møller R, et al. Imbalanced host response to SARS-CoV-2 drives development of COVID-19. Cell. 2020; 181: 1036-1045.

41. Shah VK, Firmal P, Alam A, Ganguly D, Chattopadhyay S. Overview of Immune Response During SARS-CoV-2 Infection: Lessons from the Past. Frontiers in Immunology. 2020; 11: 1949.

42. Crotty S. T follicular helper cell biology: a decade of discovery and diseases. Immunity. 2019; 50: 1132-1148.

43. Elizaldi S, Lakshmanappa YS, Roh J, Schmidt B, Carroll T, Weaver K, et al. SARS-CoV-2 infection induces robust germinal center CD4 T follicular helper cell responses in rhesus macaques. 2020 
44. Reiss S, Baxter AE, Cirelli KM, Dan JM, Morou A, Daigneault A, et al. Comparative analysis of activation induced marker (A.I.M.) assays for sensitive identification of antigen-specific CD4 T cells. PLoS One. 2017; 12: e0186998.

45. Jeyanathan M, Afkhami S, Smaill F, Miller MS, Lichty BD \& Xing Z. Immunological considerations for COVID-19 vaccine strategies. Nature reviews. Immunology. 2020; 20: 615-632.

46. World Health Organization. Draft landscape of COVID-19 candidate vaccines. WHO. 2021.

47. Roper RL \& Rehm KE. SARS vaccines: where are we?. Expert review of vaccines. 2009; 8: 887-898

48. Dong $\mathrm{Y}$, Dai $\mathrm{T}$, Wei $\mathrm{Y}$, et al. A systematic review of SARS-CoV-2 vaccine candidates. Sig Transduct Target Ther. 2020; 5: 237.

49. Afrough B, Dowall S \& Hewson R. Emerging viruses and current strategies for vaccine intervention. Clinical and experimental immunology. 2019; 196: $157-166$

50. Pardi N, Hogan MJ, Porter FW \& Weissman D. mRNA vaccines - a new era in vaccinology. Nature reviews. Drug discovery. 2018; 17: 261-279.

51. Wang F, Kream RM \& Stefano GB. An Evidence Based Perspective on mRNA-SARS-CoV-2 Vaccine Development. Medical science monitor: international medical journal of experimental and clinical research. 2020; 26 : e924700.

52. Hobernik D \& Bros M. D.N.A. Vaccines-How Far From Clinical Use? International journal of molecular sciences. 2018; 19: 3605.

53. Enjuanes L, Zuñiga S, Castaño-Rodriguez C, Gutierrez-Alvarez J, Canton J \& Sola I. Molecular Basis of Coronavirus Virulence and Vaccine Development. Advances in virus research. 2016; 96: 245-286.

54. Chen WH, Strych U, Hotez PJ \& Bottazzi ME. The SARS-CoV-2 Vaccine Pipeline: an Overview. Current tropical medicine reports. 2020: 1-4.

55. Funk $C D$, Laferrière $C$, Ardakani $A$. A snapshot of the global race for vaccines targeting SARS-CoV-2 and the COVID-19 pandemic. Frontiers in Pharmacology. 2020; 11: 937.

56. Hoffmann M, Kleine-Weber H, Pöhlmann S. A multibasic cleavage site in the spike protein of SARS-CoV-2 is essential for infection of human lung cells. Mol Cell. 2020; 78: 779-784.

57. Bao L, Deng W, Huang B, Gao H, Liu J, Ren L, et al. The pathogenicity of SARS-CoV-2 in hACE2 transgenic mice. Nature. 2020; 583: 830-833.

58. Lamers MM, Beumer J, van der Vaart J, Knoops K, Puschhof J, Breugem $\mathrm{TI}$, et al. SARS-CoV-2 productively infects human gut enterocytes. Science. 2020; 369: 50-54.

59. He C, Qin M, Sun X. Highly pathogenic coronaviruses: thrusting vaccine development in the spotlight. Acta Pharmaceutica Sinica B. 2020; 10: 11751191.

60. Keech C, Albert G, Cho I, Robertson A, Reed P, Neal S, et al. Phase 1-2 Tria of a SARS-CoV-2 Recombinant Spike Protein Nanoparticle Vaccine. The New England journal of medicine. 2020

61. Jackson LA, Anderson EJ, Rouphael NG, Roberts PC, Makhene M, Cole $\mathrm{RN}$, et al. An mRNA vaccine against SARS-CoV-2-preliminary report. N Eng J Med. 2020; 383: 1920-1931.

62. Folegatti PM, Ewer KJ, Aley PK, Angus B, Becker S, Belij-Rammerstorfer S et al. Safety and immunogenicity of the ChAdOx1 nCoV-19 vaccine against SARS-CoV-2: a preliminary report of a phase $1 / 2$, single-blind, randomized controlled trial. The Lancet. 2020.

63. Zhu FC, Li YH, Guan XH, Hou LH, Wang WJ, Li JX, et al. Safety, tolerability, and immunogenicity of a recombinant adenovirus type- 5 vectored COVID-19 vaccine: a dose-escalation, open-label, non-randomized, first-in-human trial. Lancet. 2020; 395: 1845-1854.

64. Kim E, Erdos G, Huang S, Kenniston TW, Balmert SC, Carey CD, et al. Microneedle array delivered recombinant coronavirus vaccines: Immunogenicity and rapid translational development. EBioMedicine. 2020;
55: 102743.

65. Lunar-Cov19. Arcturus Therapeutics and Duke-NUS-LUNAR-COV19. 2020.

66. Shimpei Kasagi, Dandan Wang, Pin Zhang, Peter Zanvit, Hua Chen, Dunfang Zhang, et al. Combination of apoptotic $T$ cell induction and self-peptide administration for therapy of experimental autoimmune encephalomyelitis. EBioMedicine. 2019; 44: 50-59.

67. Corey L, Mascola JR, Fauci AS, Collins FS. A strategic approach to COVID-19 vaccine R\&D: A public-private partnership and platform for harmonized clinical trials aims to accelerate licensure and distribution. Science. 2020; 368: 948-950.

68. Bournazos S, Gupta A, Ravetch JV. The role of IgG Fc receptors in antibodydependent enhancement. Nature Reviews Immunology. 2020; 20: 633-643.

69. Ruckwardt TJ, Morabito KM \& Graham BS. Immunological Lessons from Respiratory Syncytial Virus Vaccine Development. Immunity. 2019; 51: 429442.

70. Iankov ID, Pandey M, Harvey M, Griesmann GE, Federspiel MJ \& Russell SJ. Immunoglobulin $g$ antibody-mediated enhancement of measles virus infection can bypass the protective antiviral immune response. Journal of virology. 2006; 80: 8530-8540.

71. Katzelnick LC, Gresh L, Halloran ME, Mercado JC, Kuan G, Gordon A, et al. Antibody-dependent enhancement of severe dengue disease in humans. Science (New York, N.Y.). 2017; 358: 929-932.

72. Liu L, Wei Q, Lin Q, Fang J, Wang H, Kwok H, et al. Anti-spike IgG causes severe acute lung injury by skewing macrophage responses during acute SARS-CoV infection. J.C.I. insight. 2019; 4.

73. Garber K. Coronavirus vaccine developers wary of errant antibodies. Nat Biotechnol. 2020

74. Singh A, Singh RS, Sarma P, Batra G, Joshi R, Kaur H, et al. A Comprehensive Review of Animal Models for Coronaviruses: SARS-CoV-2, SARS-CoV and MERS-CoV. Virol Sin. 2020; 35: 290-304.

75. Singh A, Singh RS, Sarma $P$, et al. A Comprehensive Review of Animal Models for Coronaviruses: SARS-CoV-2, SARS-CoV, and MERS-CoV. Virol. Sin. 2020; 35: 290-304

76. Roberts A, Lamirande EW, Vogel L, Jackson JP, Paddock CD, Guarner J, et al. Animal models and vaccines for SARS-CoV infection. Virus Res. 2008; 133: 20-32.

77. Sharma O, Sultan AA, Ding H \& Triggle CR. A Review of the Progress and Challenges of Developing a Vaccine for COVID-19. Frontiers in Immunology. 2020; $11: 585354$.

78. Paula Span. Older Adults May Be Left Out of Some Covid-19 Trials. 2020.

79. Corey L, Mascola JR, Fauci AS \& Collins FS. A strategic approach to COVID-19 vaccine R\&D. Science (New York, N.Y.). 2020; 368: 948-950.

80. Gothelf A \& Gehl J. What you always needed to know about electroporation based D.N.A. vaccines. Human vaccines \& immunotherapeutics. 2012; 8 : 1694-1702

81. Omna Sharma, Ali A Sultan, Hong Ding and Chris R Triggle. A Review of the Progress and Challenges of Developing a Vaccine for COVID-19. Front. Immunol. 2020

82. Makhoul M, Ayoub HH, Chemaitelly H, Seedat S, Mumtaz GR, Al-Omari S et al. Epidemiological Impact of SARS-CoV-2 Vaccination: Mathematical Modeling Analyses. Vaccines. 2020; 8: 668.

83. Malik YS, Kumar N, Sircar S, Kaushik R, Bhat S, Dhama K, et al. Coronavirus Disease Pandemic (COVID-19): Challenges and a Global Perspective. Pathogens (Basel, Switzerland). 2020; 9: 519.

84. Jamrozik E, Selgelid MJ. COVID-19 human challenge studies: ethical issues. The Lancet Infectious Diseases. 2020; 20: E198-E203.

85. Wilder-Smith A, Hombach J, Ferguson N, Selgelid M, O'Brien K, Vannice K, et al. Deliberations of the strategic advisory group of experts on immunization on the use of CYD-TDV dengue vaccine. The Lancet infectious diseases. 2019; 19: e31-e38. 
86. Rakib A, Paul A, Chy M, Uddin N, Sami SA, Baral SK, et al. Biochemical and Computational Approach of Selected Phytocompounds from Tinospora crispa in the Management of COVID-19. Molecules. 2020; 25: 3936.

87. Rakib A, Sami SA, Mimi NJ, Chowdhury MM, Eva TA, Nainu F, et al. Immunoinformatics-guided design of an epitope-based vaccine against severe acute respiratory syndrome coronavirus 2 spike glycoprotein. Comput Biol Med. 2020: 103967.

88. Qin C, Zhou L, Hu Z, Zhang S, Yang S, Tao Y, et al. Dysregulation of immune response in patients with coronavirus 2019 (COVID-19) in wuhan, china Clinical Infectious Diseases: An Official Publication of the Infectious Diseases Society of America. 2020; 71: 762-768.

89. Conti P, Ronconi G, Caraffa AL, Gallenga CE, Ross R, Frydas I, et al Induction of pro-inflammatory cytokines (IL-1 and IL-6) and lung inflammation by coronavirus-19 (COVI-19 or SARS-CoV-2): Anti-inflammatory strategies. J Biol Regul Homeost Agents. 2020; 34: 327-331.

90. Gorse GJ, Donovan MM \& Patel GB. Antibodies to coronaviruses are higher in older compared with younger adults and binding antibodies are more sensitive than neutralizing antibodies in identifying coronavirus-associated illnesses. Journal of Medical Virology. 2020; 92: 512-517.

91. Li Z, Yi Y, Luo X, Xiong N, Liu Y, Li S, et al. Development and clinical application of a rapid IgM-IgG combined antibody test for SARS-CoV-2 infection diagnosis. Journal of Medical Virology. 2020; 92: 1518-1524.
92. Mulligan MJ, Lyke KE, Kitchin N, Absalon J, Gurtman A, Lockhart S, et al. Phase $1 / 2$ study of COVID-19 RNA vaccine BNT162b1 in adults. Nature. 2020; 586: 589-593.

93. Gao Q, Bao L, Mao H, Wang L, Xu K, Yang M, et al. Development of an inactivated vaccine candidate for SARS-CoV-2. Science. 2020; 369: 77-81.

94. Munster VJ, Feldmann F, Williamson BN, Van Doremalen N, Pérez-Pérez L, Schulz J, et al. Respiratory disease and virus shedding in rhesus macaques inoculated with SARS-CoV-2. BioRxiv. 2020.

95. Yu P, Qi F, Xu Y, Li F, Liu P, Liu J, et al. Age-related rhesus macaque models of COVID-19. Animal Models and Experimental Medicine. 2020; 3: 93-97.

96. Lu S, Zhao Y, Yu W, Yang Y, Gao J, Wang J, et al. Comparison of nonhuman primates identified the suitable model for COVID-19. Signal Transduction and Targeted Therapy. 2020; 5: 157.

97. Gu H, Chen Q, Yang G, He L, Fan H, Deng Y, et al. Rapid adaptation of SARS-CoV-2 in BALB/c mice: Novel mouse model for vaccine efficacy. bioRxiv. 2020. 